\title{
Stabilize the Emotional Through Coworker Support and Self Efficacy and Its Impact on Performance
}

\author{
Arini Novandalina ${ }^{1}$ \\ ${ }^{1}$ Doctoral Management Program of Sultan Agung Islamic University Semarang, Indonesia \\ *Corresponding author. Email: arini.novandalina@gmail.com
}

\begin{abstract}
The ability to stabilize the emotions will help to shape the individual reality-oriented perceptions of the organizations, improve the ability to assess and evaluate the capability and helps in understanding the realities of life and to face the adverse situations in life. Self efficacy needs togive one's strebgth in facing the unpleasant conditions in the organization. The influence of self-efficacy on emotional stability is rarely held so in these studies is purposed to find how does the influence of coworker support and self efficacy on emotional stability and performance.

Based on data analysis obtained from 97 respondents of the the Dinas pemberdayaan perempuan dan KB Kota Semarang. The data obtainaed were processed by statistical software PLS show that coworker support and self-efficacy have positive and significant influence on emotional stability. Coworker support does not have a significant influence on the human resources performance. Self-efficacy and emotional stability have a positive significant effect in improving performance.
\end{abstract}

Keywords: Coworker Support, Self-Efficacy, Emotional Stability and Performance.

\section{INTRODUCTION}

Challenging service in new normal era encounters to drain one's emotional resources, and emotional support could facilitate one's emotional recovery, where one's overall sense of well-being is restored. Organizational support is an organizational effort in providing appreciation, attention and expectation to employees, this organizational support shows that the organization not only drains human resources and minds but also pays attention to HR needs for emotional support Colleague support is one of the organizational support dimensions, stimulate morale support from collegue in work environtment hopefully colleagues support at work can increase the emotional stability of HR [1].

Emotional stability is the degree of calm, selfconfidence and a feeling of security [2]. Emotional stability is the concept of a person's non-cognitive multiple psychological traits [3]. Emotional stability define as a process in which a person trying to have a personality and feeling more sensitive [4]. Emotional stability support the struggle of facing the problem in life. The ability to stabilize the emotion will enhance the ability to increase the ability to assess and evaluation skills and helps in understanding the realities of life and dealing with bad situations in life [2].
Dealing with unpleasant conditions in the organization, one must have high self-confidence [5]. These individual abilities must be trained and managed effectively to achieve individual goals Human resources must have different abilities by being able to organize strategies according to goals and to complete these strategies well even in difficult circumstances [6].

People who are unable to control their negative emotions in the face of provocation and stress will find it easier to express negative feelings such as anger and irritation or may be overwhelmed by fear, anxiety and depression. People who are unable to properly express their positive emotions lose out on the social benefits that may result from fully enjoying and sharing positive feelings with others [5]. Self-efficacy leads to setting challenging goals and surfvive the difficulties [7]. A person with high self-efficacy will be able to overcome all problems that threaten his existence [8].

The effect of self-efficacy on emotional stability has not been widely studied. Individuals with high selfefficacy have more stable emotional behavior than those with low self-efficacy [5]. Research claim that selfefficacy had a significant influence on the performance of the HR [8]-[10] it is contrary to the results of [11] and [12] which state that self-efficacy has no significant 
effect on performance. Research on coworker support and work involvement has not been widely obtained, so the references obtained are still very limited in the existing literature. research indicates that peer support has an effect on HR performance [13]. The support provided by colleagues increases the feeling of comfort in working in the organization by fulfilling the need for appreciation, feelings of approval, and affiliation / friendship so that individuals have good emotional stability, regardless of cynicism about their work [14]. From the preview research above we can conclude that emotional stability has an influence on improving performance. The higher self-confidence / self-efficacy, the higher the HR performance .

\section{LITERATURE REVIEW}

\section{HR Performance ( Performance)}

HR performance is basically what $\mathrm{HR}$ does and doesn't do[15]. HR performance define as the level of satisfaction in the decision-making process where the decision is in the form of quality, participation and member agreement [16]. HR performance is the result of work completed by each HR so that it contributes to the organization [17]. Factors that influence individual workforce performance are: Indicators used in this study are quality of work, quantity of work, and timeliness [18]. Based on several definitions of $\mathrm{HR}$ performance according to the experts above, it can be concluded that HR performance is the result of work or decision making at work in the form of output quantity and quality of output achieved by HR effectively based on ability, motivation and opportunity accompanied by responsibility.

\section{Self Efficacy}

Self-efficacy is a generative ability possessed by individuals including cognitive, social and emotional [19]. These individual abilities must be trained and managed effectively to achieve individual goals. This is what Bandura calls self-efficacy because according to Bandura he has different abilities by being able to organize strategies according to goals and to complete these strategies well even in difficult circumstances [6]. Self-efficacy is a concept that specifically controls belief in an individual's ability to perform certain goals [10]. Emotion doubts can affect the abilities of an individual so that these abilities do not arise, because these doubts can weaken confidence to achieve a certain goal[6].

Based on the description presented, it can be concluded that self-efficacy is the belief and ability that individuals have in achieving goals with task difficulties in various conditions, being able to think positively, selfregulating, and positive beliefs. Several important factors that influence self-efficacy, namely the experience of success ( Mastery Experience) and the experience of others (Vicarious Experience or Modeling) [6].

The effect of self-efficacy on emotional stability has not been widely studied. Individuals with high selfefficacy have more stable emotional behavior than those with low self-efficacy [20]. So it can be concluded that self-efficacy will increase one's emotional stability. So that the hypothesis formulated is:

H1: The heigher the self efficacy, the better emotional stability

The research showed that self efficacy has a significant effect on performance [21]. The higher the self-confidence / self-efficacy, the higher the HR performance. So that the hypothesis formulated is:

H2 : The higher the self-efficay, the higher the HR Performance

\section{Coworker support}

Co-worker support shows the amount of support provided by colleagues in the work environment, coworker assistance can be in the form of attention, job assistance, and information about work Support provided by co-workers increases the feeling of comfort in working in the organization by meeting the need for appreciation, feeling of approval , and affiliation / friendship[1]. Employees who are emotionally satisfied with their work experience and years of work will have an emotional bond with the organization that supports them [22]. So it can be concluded that Coworker Social Support is interpreted as the availability of support from colleagues to fellow workers to jointly complete work. The indicators used in this study are always willing to help when needed, caring about physical and mental health, helping to develop my skills and competencies, and colleagues willing to share their work experience.

Research on the support of colleagues and emotional stability / emotional stability is not so much earned so references obtained are still very limited in the existing literature [23]. Support provided by colleagues increases a feeling of comfort in working in an organization by meeting the need for appreciation, feelings of approval, and affiliation / friendship so that individuals have good emotional stability, regardless of cynicism about their work [16], [23].

H3: The higher the support from colleagues, the higher emotional stability

A research indicates that peer support has an effect on HR performance[16], [16], [22]-[24]. This shows that the higher the support of colleagues, the higher one's performance. Research on the support of Peers and performance indicates that the coworker support affect the performance of the HR. Management must ensure that the work environment consists of supportive supervisors and coworkers who are trained on how they 
can enhance cooperation and collaboration among employees [23]. This shows that the higher the support of colleagues, the higher one's performance.

H4: The higher coworker support will enhance the employee performance

\section{Emotional stability}

Personality according to [11]is a reflection of the physical, mental, moral and social qualities of a dynamic and integrated individual, which is manifested in a unique and stable way of thinking, feeling and acting that characterizes a person towards living conditions which includes aspects: consciousness (conscientiousness), extraversion (extravertion), hospitality (agreeableness), emotional stability (emotional stability) and openness to experience (opinnese to experience) As justice is a person's perception of honesty or justice is done by the authorities in decision making about the outcomes obtained [6]. Emotional stability is a personality dimension that describes personality that describes a person's resistance to pressure or stress [3]. Emotional Stability means having a stable feeling that is not easily influenced from the outside (which is not believed and is contrary to people's beliefs) [5].

So it can be concluded that Emotional stability is the degree of calmness, self-confidence and a sense of security. Emotional stability indicators used in this study are optimism, calm, tolerance, autonomy, empathy [14]. The results of research state that emotional stability has an influence on improving HR performance [1]-[3], [5], [20].

H5: The higher emotional stability, then se increasingly high-performance HR

\section{RESEARCH METHODS}

This research was conducted to test the hypothesis with the intention of confirming or strengthening the hypothesis with expectations, which in turn can strengthen the theory that is used as a basis. The population in this study were 97 human resources in the Women's Community Empowerment Agency and KB in Semarang City with the criteria of having a minimum work period of 5 years. The sampling method uses proportional random sampling method where all individuals in the population are given the same opportunity to be selected as members of the sample. The analysis used to answer the hypothesis is structural equation modeling using the Partial Least Square (PLS) approach .

\section{Statistic Analysis}

The validity test is used to measure whether a questionnaire is valid or not. The test was carried out by using convergent validity and discriminant validity. .
Table 1: RESEARCH VARIABLES VALIDITY TEST RESULTS

\begin{tabular}{|l|l|l|l|l|}
\hline & $\begin{array}{l}\text { coworker } \\
\text { support } \\
(\mathbf{x 2})\end{array}$ & $\begin{array}{l}\text { Emot } \\
\text { stability } \\
(\mathbf{y} 1)\end{array}$ & $\begin{array}{l}\text { performance } \\
(\mathbf{y} 2)\end{array}$ & $\begin{array}{l}\text { self } \\
\text { efficacy } \\
\text { (x1) }\end{array}$ \\
\hline $\mathrm{x} 1.1$ & & & & 0.970 \\
\hline $\mathrm{x} 1.2$ & & & & 0.943 \\
\hline $\mathrm{x} 2.1$ & 0.793 & & & \\
\hline $\mathrm{x} 2.2$ & 0.243 & & & \\
\hline $\mathrm{x} 2.3$ & 0.783 & & & \\
\hline $\mathrm{x} 2.4$ & 0824 & & & \\
\hline $\mathrm{x} 2.5$ & -0.296 & & & \\
\hline $\mathrm{x} 2.6$ & -0.108 & & & \\
\hline y1.1 & & 0.655 & & \\
\hline $\mathrm{y} 1.2$ & & 0.646 & & \\
\hline $\mathrm{y} 1.3$ & & 0.651 & & \\
\hline $\mathrm{y} 1.4$ & & 0830 & & \\
\hline $\mathrm{y} 2.1$ & & & 0.603 & \\
\hline $\mathrm{y} 2.2$ & & & 0.835 & \\
\hline $\mathrm{y} 2.3$ & & & 0.855 & \\
\hline Bas & & & & \\
\hline
\end{tabular}

Based on the results of the validity test that has been carried out, it is known that not all questionnaire items that will be used to collect all data are valid with the results of convergent validity $<0.7$ which means that they can not be used in research.

Table 2: RESEARCH VARIABLES VALIDITY TEST RESULTS AFTER CUTING

\begin{tabular}{|l|l|l|l|l|}
\hline & $\begin{array}{l}\text { coworker } \\
\text { support } \\
(\mathrm{x} 2)\end{array}$ & $\begin{array}{l}\text { Emot } \\
\text { stability } \\
(\mathrm{y} 1)\end{array}$ & $\begin{array}{l}\text { performance } \\
(\mathrm{y} 2)\end{array}$ & $\begin{array}{l}\text { self } \\
\text { efficacy } \\
(\mathrm{x} 1)\end{array}$ \\
\hline $\mathrm{x} 1.1$ & $\mathrm{x} 1.2$ & & & \\
\hline $\mathrm{x} 2.1$ & 0.793 & & & 0.970 \\
\hline $\mathrm{x} 2.2$ & 0.263 & & & \\
\hline $\mathrm{x} 2.3$ & 0.783 & & & \\
\hline $\mathrm{x} 2.4$ & 0.825 & & & \\
\hline $\mathrm{y} 1.1$ & & 0.656 & & \\
\hline $\mathrm{y} 1.2$ & & 0.647 & & \\
\hline $\mathrm{y} 1.3$ & & 0.649 & & \\
\hline $\mathrm{y} 1.4$ & & 0830 & & \\
\hline
\end{tabular}




\begin{tabular}{|l|l|l|c|l|}
\hline y2.1 & & & 0.606 & \\
\hline y2.2 & & & 0.834 & \\
\hline y2.3 & & & 0854 & \\
\hline
\end{tabular}

Based on the validity of the test results that have been done, it is known that all item questionnaire that will be used to collect the data is valid all the results of convergent validity $>0,5$ which means it can be used in research. To test the discriminant validity is done with $\mathrm{k}$ orelasi construct with its own indicator or construct correlation with other indicators.

Table 3: CONSTRUCT CORRELATION VALUE WITH INDICATORS

\begin{tabular}{|r|r|r|r|r|}
\hline & \multicolumn{1}{|l|}{$\begin{array}{l}\text { coworker } \\
\text { support }\end{array}$} & \multicolumn{1}{c|}{$\begin{array}{l}\text { Emot } \\
\text { stability }\end{array}$} & \multicolumn{1}{l|}{ Kinerja } & \multicolumn{1}{l|}{$\begin{array}{l}\text { self } \\
\text { efficacy }\end{array}$} \\
\hline $\mathbf{x 1 . 1}$ & 0.247 & 0.527 & 0.249 & 0.970 \\
\hline $\mathbf{x 1 . 2}$ & 0.207 & 0.381 & 0.184 & 0.943 \\
\hline $\mathbf{x 2 . 1}$ & 0.793 & 0.677 & 0.619 & 0.260 \\
\hline $\mathbf{x 2 . 2}$ & 0.263 & 0.164 & 0.097 & 0.172 \\
\hline $\mathbf{x 2 . 3}$ & 0.783 & 0.496 & 0.591 & 0.181 \\
\hline $\mathbf{x 2 . 4}$ & 0.825 & 0.578 & 0.709 & 0.112 \\
\hline $\mathbf{y 1 . 1}$ & 0.364 & 0.656 & 0.386 & 0.044 \\
\hline $\mathbf{y 1 . 2}$ & 0.414 & 0.647 & 0.426 & 0.206 \\
\hline $\mathbf{y 1 . 3}$ & 0.384 & 0.649 & 0.355 & 0.818 \\
\hline $\mathbf{y 1 . 4}$ & 0.762 & 0830 & 0.738 & 0.245 \\
\hline $\mathbf{y 2 . 1}$ & 0.452 & 0.490 & 0.606 & 0.203 \\
\hline $\mathbf{y 2 . 2}$ & 0.654 & 0.524 & 0.834 & 0.104 \\
\hline $\mathbf{y 2 . 3}$ & 0.699 & 0.645 & 0854 & 0.234 \\
\hline
\end{tabular}

The discriminant validity test can be seen that these requirements have been met so that all the constructs in the estimated model meet good discriminant validity criteria , meaning that the results of data analysis can be accepted because the value that describes the relationship between the constructs develops.

Measurement of reliability using 2 (two) ways, namely Composite Reliability and Average Variance Extracted (AVE).

Table 4: Value Of Composite Reliability and Average Variance Extracted

\begin{tabular}{|l|c|l|}
\hline & AVE & CR \\
\hline Coworker support & 0.698 & $\mathbf{0 . 7 8 0}$ \\
\hline Emotional stability & 0.690 & $\mathbf{0 . 7 9 1}$ \\
\hline Performance & 0.597 & $\mathbf{0 . 8 1 3}$ \\
\hline Self efficacy & 0.916 & $\mathbf{0 . 9 5 6}$ \\
\hline
\end{tabular}

Average Variance Extracted obtained is > 0, 5 means that it has a good reliability value and can be used for the research process . The composite reliability of the overall variable is $>0.7$ means to have a good reliability value and can be used for further research process.

To determine whether a hypothesis is accepted or not by comparing $\mathrm{t}$ count with $\mathrm{t}$ table with the condition that if $\mathrm{t}$ count $>\mathrm{t}$ table, then the hypothesis is accepted. For more details can be seen on $\mathrm{T}$ abel 4 below.

Table 5: HYPOTHESIS TEST

\begin{tabular}{|l|l|l|l|l|l|}
\hline & $\begin{array}{l}\text { Origina } \\
1 \\
\text { Sample } \\
(\mathrm{O})\end{array}$ & $\begin{array}{l}\text { Sampl } \\
\mathrm{e} \\
\text { Mean } \\
(\mathrm{M})\end{array}$ & $\begin{array}{l}\text { Standard } \\
\text { Deviatio } \\
\mathrm{n} \\
(\text { STDEV } \\
)\end{array}$ & $\begin{array}{l}\text { T Statistics } \\
(\mid \mathrm{O} / \text { STDEV } \\
()\end{array}$ & $\begin{array}{l}\text { P } \\
\text { Value } \\
\mathrm{s}\end{array}$ \\
\hline $\begin{array}{l}\mathrm{X} 2 \\
\rightarrow \square \mathrm{y} \\
1\end{array}$ & 0.653 & 0.661 & 0.047 & 13,835 & 0.000 \\
\hline $\begin{array}{l}\mathrm{X} 2 \\
\rightarrow \square \mathrm{y} 2\end{array}$ & 0.554 & 0.574 & 0.091 & 6,103 & 0.000 \\
\hline $\begin{array}{l}\mathrm{Y} 1 \\
\rightarrow \square \mathrm{y} 2\end{array}$ & 0.347 & 0.331 & 0.094 & 3,684 & 0.000 \\
\hline $\begin{array}{l}\mathrm{X} 1 \\
\rightarrow \square \mathrm{y} 1\end{array}$ & 0.329 & 0.330 & 0.064 & 5,170 & 0.000 \\
\hline $\begin{array}{l}\mathrm{X} 1 \\
\rightarrow \square \mathrm{y} 2\end{array}$ & -0.070 & -0.067 & 0.068 & 1,032 & 0.303 \\
\hline
\end{tabular}

Information : x 1: Self efficacy ; x $2: \mathrm{c}$ oworker support ; y 1 : e motional stability ; y 2:performance

The results of data processed using PLS software tools, the loading factor construct structure model which will explain the relationship between the constructs is shown in the following figure :

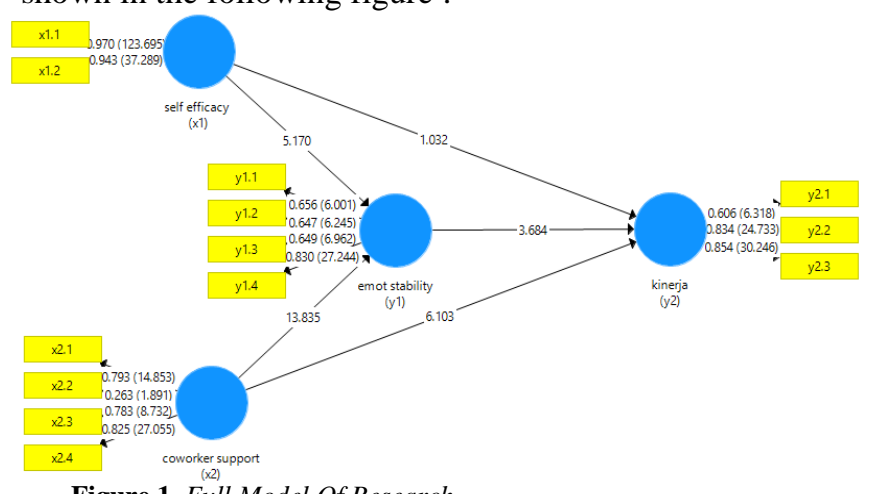

Figure 1. Full Model Of Research

Then the equation formed based on table 5 is:

Equation 1: $\mathrm{Y}_{1}=0,329 \mathrm{X}_{1}+0,653 \mathrm{X}_{2}+e$

Equation 2: $\mathrm{Y}_{2}=-0,070 \mathrm{X}_{1}+0,347 \mathrm{X} 2+0,554$

$\mathrm{Y}_{1+e}$ 
The results of the data processed above and the hypothesis that has been proposed, are as follows :

1) Coworker support positively significant influence to the emotional stability means coworker support will increase emotional stability. Coworker support shows the amount of support provided by colleagues in the work environment, co-worker assistance can be in the form of attention, job assistance, and information about work. The support provided by colleagues increases the feeling of comfort in working in the organization by fulfilling the need for appreciation, feelings of approval, and affiliation / friendship. Employees who are emotionally satisfied with their work experience and years of work will have an emotional bond with the organization that supports them. Support provided by colleagues increases the feeling of comfort in working in the organization by fulfilling the need for appreciation, feelings of approval, and affiliation / friendship so that individuals have good emotional stability, regardless of cynicism about their work.

2) Coworker support has the effect is positive but not significant to the performance of human resources. This shows that the higher the support of colleagues, the higher one's performance. The support provided by co-workers is not able to increase the feeling of comfort in working in the organization because of the feeling of not wanting to be competed, decreasing the independence of human resources so that they always rely on help / support from colleagues in completing their work. This is indicated if colleagues are always willing to help when needed, it will make HR unable to meet the quality and quantity targets set by the organization , when colleagues feel concerned about physical and mental health it will cause excessive tolerance levels for the health conditions of their colleagues so that unable to meet the quality and quantity targets set by the organization. If colleagues recognize strengths / strengths and weaknesses and are able to communicate matters related to work, this increases the intensity of human resources in socializing with their respective colleagues, resulting in inaccurate time for completing work. When colleagues help develop skills and competencies and are willing to share their work experience, it will increase the intensity of communication between colleagues so that the time for carrying out work is reduced .

3) self efficacy has positive signivicant towards emotional stability, meaning that the higher selfefficacy will increase emotional. So it can be concluded that the higher self-efficacy will increase one's emotional stability. Self-efficacy is one of the most influential aspects in determining the actions to be taken to achieve a goal, including an estimate of the challenges that will be faced. Self-efficacy determines how to survive and behave in the face of difficulties. A person with high self-efficacy will be able to overcome all problems that threaten his existence. Self-efficacy is generally understood as a specific or specific task, but self-efficacy also refers to the belief in an individual's ability to cope with various demands and situations .

4) self-efficacy has significant effect on performance HR means that the higher self-efficacy will improve performance. The higher self-confidence / selfefficacy, the higher the HR performance. Successful experiences strengthen self-confidence to be able to meet the quality and quantity of work standardized by the organization. The experiences of others become role models /examples to achieve success in meeting the target time / time line set by the organization.

5) Emotional stability of the performance of HR means that the high emotional stability that will improve the performance of HR. HR with high emotional stability will have a behavior optimistic, calm, tolerance, autonomy and empathy so as to increase the gain of the target of the quality, quantity and deadlines set by the organization. emotional stability shows a person's ability to deal with pressure calmly, confidently, and safely. emotional stability give peace to someone in the face and understand the problems of life. Capacity of stabilizing the emotions will help the organization in shaping the perception of the individual will be the organization that is oriented to the realities that exist, improve the ability to assess and evaluation capability s erta assist in understanding the realities of life and to face adverse situations in life.

Assessing the inner workings of the model is mengeval $u$ ation relationships among latent constructs as had been hypothesized, where the relationship of each construct was measured with two latent constructs.

Table 4. 19: $R$-SQUARE VALUE $\left(\mathrm{R}^{2}\right)$

\begin{tabular}{|l|l|}
\hline & R Square \\
\hline Emotional satability & 0.506 \\
\hline Performance (y2) & 0.755 \\
\hline
\end{tabular}

Based on the $R$ square value, it shows that variations in HR performance can be explained by emotional stability, self-efficacy and coworker support by $75.5 \%$, the remaining $24.5 \%$ is explained by variations in other variables that are not included in the model. The variation of emotional stability can be explained by self-efficacy and coworker support of $50.6 \%$, the remaining $49.4 \%$ is explained by variations in other variables that are not included in the model. 


\section{CONCLUSION}

\section{Conclusion}

Based on the analysis and discussion in this study we can conclude that the higher coworker support and selfefficacy will improve emotional stability. Coworker support does not have significant effect of HR performance, but self-efficacy and emotional stability has significant effect in improving performance.

Based on the results of data analysis that has been done, it can be concluded that the results of this study are:

1. Self-efficacy has significant positive effect on emotional stability, means that the higher selfefficacy will increase emotional stability .

2. Coworker support has significant positive effect on emotional stability, means that the higher coworker support will increase emotional stability.

3. Self-efficacy has a significant positive effect on performance, means the higher self-efficacy that will improve performance.

4. Coworker support does not have significant influence on HR performance.

5. Emotional stability has a significant positive influence in improving performance means higher emotional stability will improve performance.

\section{Managerial Implications}

To enhance the self-efficacy, organizations are expected to provide regular experience sharing programs for their employees in order to train employee to convey aspirations and provide new information to their colleagues in the sharing forum. Success experiences increase the self-confidence and for the impact it will increase self-efficacy. With regard to coworker support organization has to pay attention related to employee physical and mental health by increasing the personal closeness between human resources by forming team building, increasing the family members of the organization. Organization must often hold joint events with its employee to ensure the communication runs effectively.

To improve the capability to stabilizing emotional of employee, organizations must improve the employee mental health development. Improving mental health will provide the ability to face the hard situation in carrying out their work. It can conducted by increasing the mental development program periodically to provide a sense of calm and comfort at work. The organization must increase the intensity of togetherness between human resources so that it can increase empathy.

To improve organizational performance, it should be able to meet the quality of work results in accordance with the procedure that the organization adheres to. This can be done by providing rewards and recognition for achievers who are able to achieve monthly, quarterly and annual performance targets. To improve the graphics performance of its employees, organizations must improve the effectiveness of human resources so that the standard time of completion of the work can be achieved.

\section{Research Limitations}

Based on the results of research and discussion, it can be seen that the weakness of this study is the low value of the original sample of estimate coworker support so that the coworker support is unable to have a significant effect on improving performance.

\section{Upcoming Research Agenda}

It is necessary to re-examine the effect of coworker support on human resources performance in other organizations with wider respondents by providing other variables that are able to influence the increase in performance. So it is necessary to conduct further research on the causal relationship between coworker support and human resources performance in other larger organizations and with a wider population and sample.

\section{REFERENCES}

[1] M. J. Tews, J. W. Michel, and K. Stafford, "Abusive Coworker Treatment, Coworker Support, and Employee Turnover," J. Leadersh. Organ. Stud., vol. 26, no. 4, pp. 413-423, 2019, doi: $10.1177 / 1548051818781812$.

[2] Y. Te Chiang, W. T. Fang, U. Kaplan, and E. Ng, "Locus of control: The mediation effect between emotional stability and pro-environmental behavior," Sustain., vol. 11, no. 3, 2019, doi: 10.3390/su11030820.

[3] B. Bajaj, R. Gupta, and S. Sengupta, "Emotional Stability and Self-Esteem as Mediators Between Mindfulness and Happiness.," J. Happiness Stud., 2018, doi: doi:10.1007/s10902-018-0046-4.

[4] S. C. Segerstrom and G. T. Smith, "Personality and Coping: Individual Differences in Responses to Emotion," Апnи. Rev. Psychol., vol. 70, no. September 2018, pp. 651-671, 2019, doi: 10.1146/annurev-psych-010418-102917.

[5] G. Caprara, M. Vecchione, C. Barbaranelli, and G. Alessandri, "Emotional stability and affective selfregulatory efficacy beliefs: Proofs of integration between trait theory and social cognitive theory," Eur. J. Pers., vol. 27, no. 2, pp. 145-154, 2013, doi: 10.1002/per.1847.

[6] A. Bandura, "On the functional properties of perceived self-efficacy revisited," J. Manage., vol. 
38, no. 1, pp. 9-44, 2012, doi: $10.1177 / 0149206311410606$.

[7] M. Faramarzi, H. Pasha, S. Esmailzadeh, F. Kheirkhah, K. Hajian-Tilaki, and H. Salmalian, "A Survey of Correlation Infertility Self-Efficacy with Behavioral Health Scales in Infertile Women," Health (Irvine. Calif)., vol. 06, no. 10, pp. 943-949, 2014, doi: 10.4236/health.2014.610119.

[8] A. A. Eniola, "Entrepreneurial self-efficacy and orientation for SME development," Small Enterp. Res., vol. 0, no. 0, pp. 1-21, 2020, doi: 10.1080/13215906.2020.1752295.

[9] F. O. Walumbwa, D. M. Mayer, P. Wang, H. Wang, K. Workman, and A. L. Christensen, "Linking ethical leadership to employee performance: The roles of leader-member exchange, self-efficacy, and organizational identification," Organ. Behav. Hum. Decis. Process., vol. 115, no. 2, pp. 204-213, 2011, doi: 10.1016/j.obhdp.2010.11.002.

[10] M. Trautner and M. Schwinger, "Integrating the concepts self-efficacy and motivation regulation: How do self-efficacy beliefs for motivation regulation influence self-regulatory success?," Learn. Individ. Differ., vol. 80, no. November 2019, 2020, doi: 10.1016/j.lindif.2020.101890.

[11] T. A. Judge, C. L. Jackson, J. C. Shaw, B. A. Scott, and B. L. Rich, "Self-efficacy and work-related performance: The integral role of individual differences," J. Appl. Psychol., vol. 92, no. 1, pp. 107-127, 2007, doi: 10.1037/0021-9010.92.1.107.

[12] H. F. Lin, "The effect of absorptive capacity perceptions on the context-aware ubiquitous learning acceptance," Campus-Wide Inf. Syst., vol. 30, no. 4, pp. 249-265, 2013, doi: 10.1108/CWIS09-2012-0031.

[13] S. Siddiqui, M. Thomas, and N. N. Soomro, "Technology integration in education: Source of intrinsic motivation, self-efficacy and performance," J. E-Learning Knowl. Soc., vol. 16, no. 1, pp. 11-22, 2020, doi: 10.20368/1971$8829 / 1135188$.

[14] A. Jawabri, "The impact of Big-5 model leadership traits on team entrepreneurship: An empirical study of small businesses in the UAE," Manag. Sci. Lett., vol. 10, no. 3, pp. 497-506, 2020, doi: 10.5267/j.msl.2019.9.031.

[15] K. Lajili, L. Y. H. Lin, and A. Rostamkalaei, "Corporate governance, human capital resources, and firm performance: Exploring the missing links," J. Gen. Manag., vol. 45, no. 4, pp. 192-205, 2020, doi: 10.1177/0306307019895949.
[16] R. Meghdad, R. Nayereh, S. Zahra, Z. Houriye, and N. Reza, "Assessment of the performance of nurses based on the 360-degree model and fuzzy multicriteria decision-making method (FMCDM) and selecting qualified nurses," Heliyon, vol. 6, no. 1, p. e03257, 2020, doi: 10.1016/j.heliyon.2020.e03257.

[17] J. F. Ybema, T. van Vuuren, and K. van Dam, “HR practices for enhancing sustainable employability: implementation, use, and outcomes," Int. J. Hum. Resour. Manag., vol. 31, no. 7, pp. 886-907, 2020, doi: 10.1080/09585192.2017.1387865.

[18] R. Aryani and W. Widodo, "Exploring the effect of employability and job characteristics on contextual performance: Mediating by organizational commitment," Manag. Sci. Lett., vol. 10, no. 9, pp. 2071-2076, 2020, doi: 10.5267/j.msl.2020.2.004.

[19] Q. M. Mutar, H. M. Mohammad, and S. H. Hmmud, "International Journal of Multicultural and Multireligious Understanding Academic Achievement and Its Relation with Self-Efficacy and Academic Adjustment in EFL Class," no. Pandora 2007, pp. 1-13, 2020.

[20] C. Cohrdes and E. Mauz, "Self-Efficacy and Emotional Stability Buffer Negative Effects of Adverse Childhood Experiences on Young Adult Health-Related Quality of Life," J. Adolesc. Heal., vol. 67, no. 1, pp. 93-100, 2020, doi: 10.1016/j.jadohealth.2020.01.005.

[21] L. Kawet and R. R. Rimper, "Pengaruh Perencanaan Karir Dan Self Efficacy Terhadap Kinerja Karyawan Pada Pt. Pln (Persero) Area Manado," J. EMBA J. Ris. Ekon. Manajemen, Bisnis dan Akunt., vol. 2, no. 4, pp. 413-423, 2014, doi: 10.35794/emba.v2i4.6345.

[22] G. Caesens, F. Stinglhamber, S. Demoulin, M. De Wilde, and A. Mierop, "Perceived organizational support and workplace conflict: The mediating role of failure-related trust," Front. Psychol., vol. 9, no. JAN, pp. 1-13, 2019, doi: 10.3389/fpsyg.2018.02704.

[23] Y. Choi, D. J. Yoon, and D. Kim, "Leader behavioral integrity and employee in-role performance: The roles of coworker support and job autonomy," Int. J. Environ. Res. Public Health, vol. 17, no. 12, pp. 1-14, 2020, doi: 10.3390/ijerph17124303.

[24] L. Rhoades and R. Eisenberger, "Perceived organizational support: A review of the literature," J. Appl. Psychol., vol. 87, no. 4, pp. 698-714, 2002, doi: 10.1037/0021-9010.87.4.698. 